\title{
Characterization and Modes of Occurrence of Elements in Feed Coal and Fly Ash-An Integrated Approach
}

\section{Introduction}

Despite certain environmental concerns, coal is likely to remain an important component of the United States energy supply, partly because it is the most abundant domestically available fossil fuel. One of the concerns about coal combustion for electricity production is the potential release of elements from coal and coal combustion products (CCPs)—fly ash-to the environment. This concern prompted the need for accurate, reliable, and comprehensive information on the contents and modes of occurrence of selected elements in power-plant feed coal and fly ash. The U.S. Geological Survey (USGS) is collaborating with several electric utilities to determine the chemical and mineralogical properties of feed coal and fly ash. Our first study analyzed coal and fly ash from a Kentucky power plant, which uses many different bituminous coals from the Appalachian and Illinois Basins. Sulfur content of these feed coals ranged from 2.5 to 3.5 percent. The second study analyzed coal and fly ash from an Indiana power plant, which uses subbituminous coal from the Powder River Basin (fig. 1). Sulfur content of this feed coal ranged from 0.23 to 0.47 percent. A summary of important aspects of our approach and results are presented in this report.

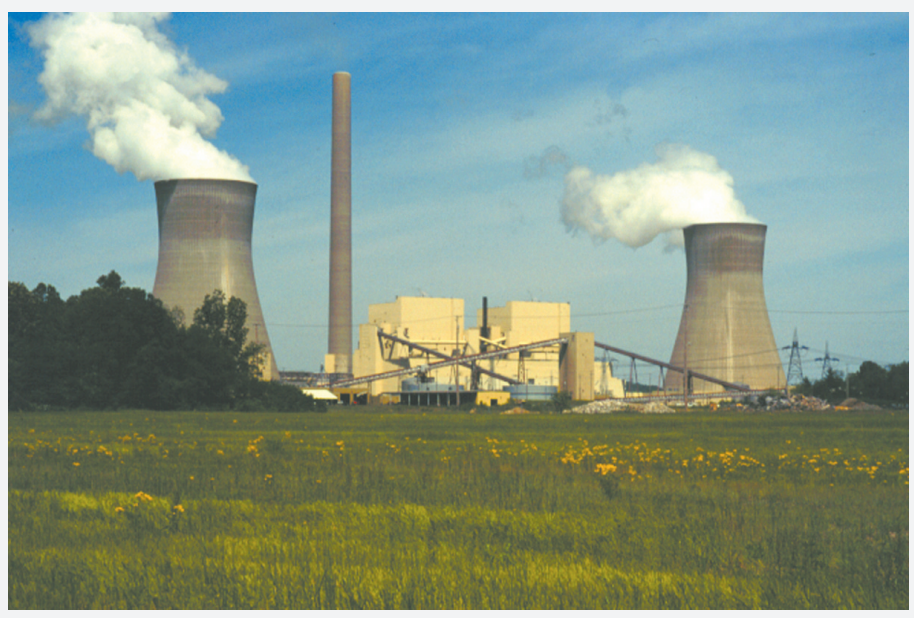

Figure 1. A coal-fired power plant in Indiana that uses low-sulfur coal from the Powder River Basin, Wyoming.

\section{Approach}

Coal is a complex combustible rock made up of organic and inorganic mineral components, which contain many elements. During combustion, elements present in the organic and mineral components of coal are redistributed, as a result of high temperatures, into new gaseous and solid phases. In the new solid phases (CCPs), the elements may be uniformly distributed throughout a grain, enriched in certain grains or areas of grains, or present as coatings on grains or adsorbed onto grain surfaces. Particle size, coal rank, amount of ash, coal mineralogy, and the trace element content are important variables controlling the combustion and mobility of elements in coal. For fly ash, the original composition of the feed coal, the combustion conditions, the size of the fly ash particles, and the fly ash mineralogy influence the distribution and mobility of trace metals.
To characterize the chemistry and mineralogy of these components, the USGS applied an analytical approach involving (1) highly sensitive chemical analysis of feed coal and fly ash, (2) radiographic techniques that quantify the distribution and abundance of radioactive particles, (3) petrographic analysis, X-ray diffraction analysis, and microbeam analysis, including element concentration mapping of small fly ash grains, and (4) analysis of leaching extracts that selectively dissolve certain components of coal or fly ash to simulate environmental conditions. To accomplish this, we organized a team of geologists, geochemists, chemists, coal technologists, and engineers from the USGS, State geologic surveys, universities, and electric utility companies.

\section{Elements in Feed Coal and Fly Ash}

Determination of elements in feed coal is important because the content, distribution, and behavior of elements during and after combustion depend in large part on the content and distribution of trace elements in the feed coal. Elements of environmental interest as defined by the 1990 Clean Air Act Amendments (U.S. Statutes at Large, 1990) are important because they can be potentially released into the environment during coal utilization. Results of chemical analyses show differences in the compositions of the feed coal stocks. Kentucky power-plant feed coals are higher in arsenic (As), chromium (Cr), cobalt (Co), iron $(\mathrm{Fe})$, lead $(\mathrm{Pb})$, and uranium $(\mathrm{U})$ than Indiana plant feed coals (table 1), whereas the Indiana power-plant feed coals are higher in barium (Ba), calcium $(\mathrm{Ca})$, magnesium $(\mathrm{Mg})$, strontium $(\mathrm{Sr})$, and phosphorus (P) than Kentucky plant feed coals (Brownfield and others, 1999). The composition of the fly ash reflects the original element content of the feed coal (table 1). The trace element content of Kentucky power-plant feed coal and fly ash analyzed in this study displayed considerable variability (Affolter and others, 1997) during the sampling period (fig. 2). As an example, figure 2 shows selected element contents in the Kentucky

Table 1. Ash yield and selected mean element contents of feed coal and fly ash from the Kentucky and Indiana power plants.

[All elements are presented on an as-determined ash basis. Mercury content on the feed coal is on a whole coal basis. * indicates elements of environmental interest according to 1990 Clean Air Act]

\begin{tabular}{|c|c|c|c|c|}
\hline \multirow[b]{2}{*}{ Element } & \multicolumn{2}{|c|}{ Kentucky power plant } & \multicolumn{2}{|c|}{ Indiana power plant } \\
\hline & Feed coal & Fly ash & Feed coal & Fly ash \\
\hline \multicolumn{5}{|c|}{ Percent } \\
\hline (ash) & 10 & & 6.2 & \\
\hline $\mathrm{Ca}$ & 2.6 & 2.6 & 16 & 21 \\
\hline $\mathrm{Fe}$ & 13 & 12 & 3.3 & 4.0 \\
\hline $\mathrm{Mg}$ & 48 & .50 & 3.5 & 3.8 \\
\hline $\mathrm{P}$ & .13 & .13 & .49 & .61 \\
\hline \multicolumn{5}{|c|}{ Parts per million } \\
\hline As* & 120 & 170 & 17 & 18 \\
\hline $\mathrm{Ba}$ & 560 & 600 & 5700 & 7400 \\
\hline $\mathrm{Cd}^{*}$ & 3.6 & 5.5 & 1.1 & 1 \\
\hline $\mathrm{Co}^{*}$ & 45 & 59 & 27 & 31 \\
\hline $\mathrm{Cr}^{*}$ & 150 & 170 & 90 & 95 \\
\hline $\mathrm{Hg}^{*}$ & .07 & .39 & .07 & .01 \\
\hline $\mathrm{Ni}^{*}$ & 170 & 220 & 56 & 75 \\
\hline $\mathrm{Pb}^{*}$ & 110 & 150 & 19 & 42 \\
\hline $\mathrm{Sr}$ & 730 & 780 & 4000 & 4200 \\
\hline $\mathrm{U}^{*}$ & 16 & 19 & 8.9 & 9.0 \\
\hline
\end{tabular}




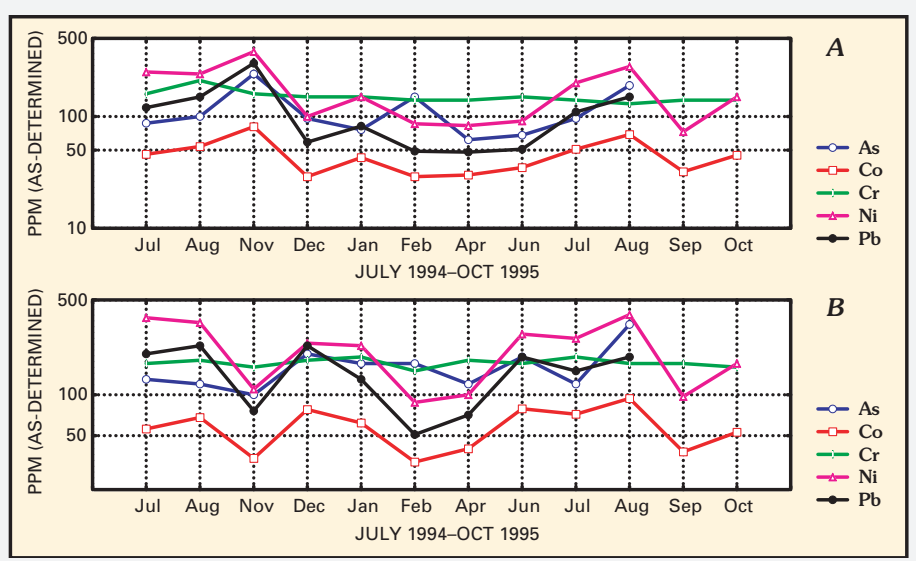

Figure 2. Temporal variation of selected elements in the feed coal (A) and in the fly ash (B) from the Kentucky power plant during the 16-month sample period.

feed coal and fly ash during the 16-month sample period. These variations reflect the multiple sources of feed coal, from numerous mines in the Illinois and Appalachian Basins (as many as 20 sources were used within one month). Indiana plant feed coal and fly ash displayed less variability (Affolter and others, 1999) because of the single coal source (Wyodak-Anderson coal zone, Powder River Basin). These studies of feed coal are important because the greater the variability within the feed coal, the greater the variability in the fly ash and the more difficult it is to predict the properties of the fly ash, including modes of occurrence of trace elements in the fly ash.

The characterization of an element in coal and what happens to that element during the combustion process is shown by the following example. Uranium content in Kentucky and Indiana feed coals is 16 and $8.9 \mathrm{ppm}$, respectively (table 1), and the uranium content of the fly ashes is 19 and 9.0 ppm, respectively. Uranium in Kentucky and Indiana feed coals is organically bound, with lesser amounts associated with uraniumbearing minerals such as apatite, monazite, and zircon. The distribution and form of radioactive elements in fly ash determine the availability of these elements for release to the environment during ash utilization or disposal. Uranium in fly ash is uniformly distributed throughout the glassy grains of the fly ash (fig. 3). The low amount of surface-bound, potentially leachable uranium suggests that the rate of release of uranium will be slow and controlled by the very slow rate at which the ash grains dissolve (Zielinski and Finkelman, 1997).
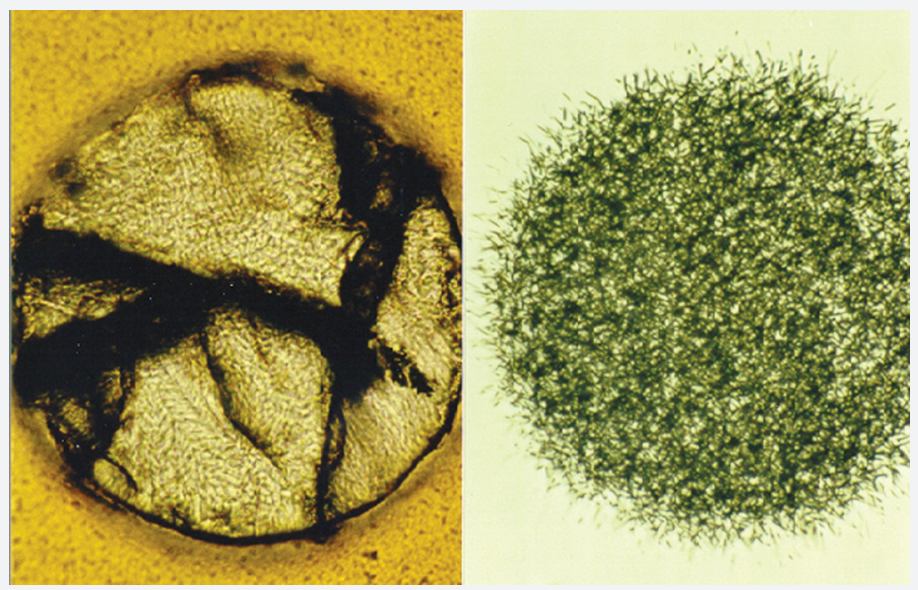

Figure 3. Photograph (left) of a glassy fly ash grain and its fission track radiograph (right) from an Indiana power plant. Uranium distribution and concentration are indicated by the location and density of the fission tracks in the radiograph. Photograph and radiograph by Robert A. Zielinski (USGS).

\section{Mineralogy of Feed Coal and Fly Ash}

Determination of minerals in coal and fly ash is important because minerals affect coal and fly ash utilization, and the location and leachability of elements, as well as control the acidity $(\mathrm{pH})$ during interaction with water. Coals mined for use in Kentucky and Indiana power plants contain common rock-forming minerals, primarily wellcrystallized quartz and kaolinite (table 2). In the Kentucky power-plant coal, higher amounts of arsenic and mercury are primarily found in pyrite; chromium is found in illite; and cadmium is found in sphalerite. In the Indiana power-plant coal, the higher amounts of barium, phosphorus, and strontium are found in crandallite group minerals and apatite.

X-ray diffraction (XRD) analysis of the Kentucky power-plant fly ash samples determined that the major components are glass, mullite, and quartz, with minor amounts of illite, hematite, and spinel group minerals (table 2). XRD analysis of the Indiana power-plant fly ash samples revealed a predominance of glass, perovskite, lime, and gehlenite, with minor amounts of quartz, apatite, periclase, and mullite (table 2). An example of the importance of studying the mineralogy of fly ash is

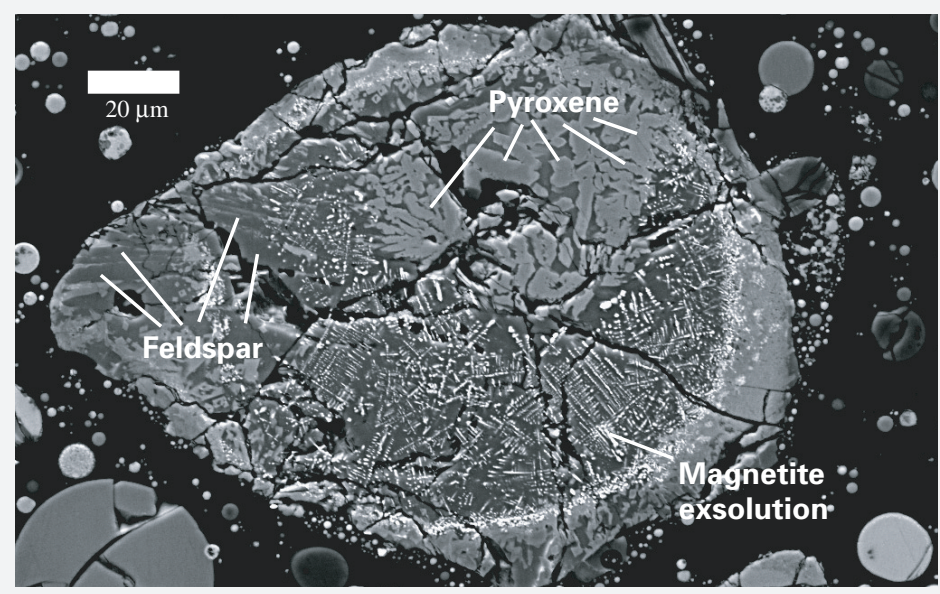

Figure 4. Scanning electron microscope image of an Indiana power-plant fly ash grain showing exsolution dendrites of chromium-bearing magnetite in a matrix of feldspar and pyroxene.

shown in figure 4. Chromium, nickel, and cobalt are elements of environmental concern. Scanning electron microscope (SEM) analysis of fly ash grains determined that these elements occur in chromium-, nickel-, and cobalt-bearing iron-oxide-rich particles (fig. 4), which are unlikely to be released to the environment.

Element intensity mapping using the electron microprobe scans the sample for relative intensity of individual elements at each counting point and helps us to develop a better understanding of modes of occurrence and potential release of selected elements to the environment. For example, figure 5 shows a distinct rim of calcium and sulfur resulting from a thin anhydrite $\left(\mathrm{CaSO}_{4}\right)$ coating on an Indiana power-plant fly ash grain (Brownfield and others, 1999).

In the Kentucky power-plant fly ash, higher amounts of arsenic, chromium, nickel, and cobalt are related to the presence of abundant pyrite and relict magnetite in the feed coal, and the higher amounts of cadmium are related to the sphalerite in the feed coal. The calcium-, magnesium-, and phosphorus-rich mineral phases in the Indiana powerplant fly ash (table 2) can be attributed to alteration of volcanic ash in the feed coal.

\section{Leaching Studies}

Coal and CCPs can alter the composition of solutions they contact through water-rock interactions. This can be a significant environmental consideration in the use of coal for energy production, especially because CCPs can be used in building materials and as soil amendments, and also are disposed of in surface impoundments. These water-rock 


\begin{tabular}{|c|c|c|c|}
\hline \multicolumn{2}{|c|}{ Kentucky power plant } & \multicolumn{2}{|c|}{ Indiana power plant } \\
\hline Feed coal & Fly ash & Feed coal & Fly ash \\
\hline Quartz-SiO $2-\mathrm{Ma}$ & Glass-Ma & Quartz-SiO ${ }_{2}$-alpha form-Ma & Glass-Ma \\
\hline Kaolinite- $\mathrm{Al}_{2} \mathrm{Si}_{2} \mathrm{O}_{5}(\mathrm{OH})_{4}-\mathrm{Ma}$ & Mullite- $\mathrm{Al}_{6} \mathrm{Si}_{2} \mathrm{O}_{13}-\mathrm{Ma}$ & Kaolinite- $\mathrm{Al}_{2} \mathrm{Si}_{2} \mathrm{O}_{5}(\mathrm{OH})_{4}-\mathrm{Ma}$ & Perovskite-CaTiO $3-\mathrm{Ma}$ \\
\hline Illite/Muscovite-Mi & Quartz-SiO $-\mathrm{Ma}$ & Carbonates- $\mathrm{CaCO}_{3}-\mathrm{Mi}$ & Lime- $\mathrm{CaO}-\mathrm{Ma}$ \\
\hline Pyrite- $\mathrm{FeS}_{2}-\mathrm{Mi}$ & Illite/Muscovite-Mi & Biotite/Muscovite-Mi & Gehlenite- $\mathrm{Ca}_{2} \mathrm{Al}(\mathrm{Al}, \mathrm{Si}) \mathrm{O}_{7}-\mathrm{Ma}$ \\
\hline Calcite- $\mathrm{CaCO}_{3}-\mathrm{Mi}$ & Hematite- $\mathrm{Fe}_{2} \mathrm{O}_{3}-\mathrm{Mi}$ & Crandallite Group-Mi & Quartz-Mi \\
\hline \multirow[t]{4}{*}{ Sphalerite- $(\mathrm{Zn}, \mathrm{Fe}) \mathrm{S}-\mathrm{Tr}$} & Magnetite- $\mathrm{FeFe}_{3} \mathrm{O}_{4}-\mathrm{Mi}$ & Quartz- $\mathrm{SiO}_{2}$-beta form- $\mathrm{Tr}$ & Apatite- $\mathrm{Ca}_{5}\left(\mathrm{PO}_{4}\right)_{3} \mathrm{~F}-\mathrm{Mi}$ \\
\hline & Magnesioferrite- $\mathrm{MgFe}_{2} \mathrm{O}_{4}-\mathrm{Mi}$ & Barite- $\mathrm{BaSO}_{4}-\mathrm{Tr}$ & Periclase- $\mathrm{MgO}-\mathrm{Mi}$ \\
\hline & Steklite-KAl $\left(\mathrm{SO}_{4}\right)_{2}-\mathrm{Tr}$ & Apatite- $\mathrm{Ca}_{5}\left(\mathrm{PO}_{4}\right)_{3} \mathrm{~F}-\mathrm{Tr}$ & Mullite- $\mathrm{Al}_{6} \mathrm{Si}_{2} \mathrm{O}_{13}-\mathrm{Mi}$ \\
\hline & & Plagioclase-Tr & Anhydrite-CaSO $4-\mathrm{Tr}$ \\
\hline
\end{tabular}

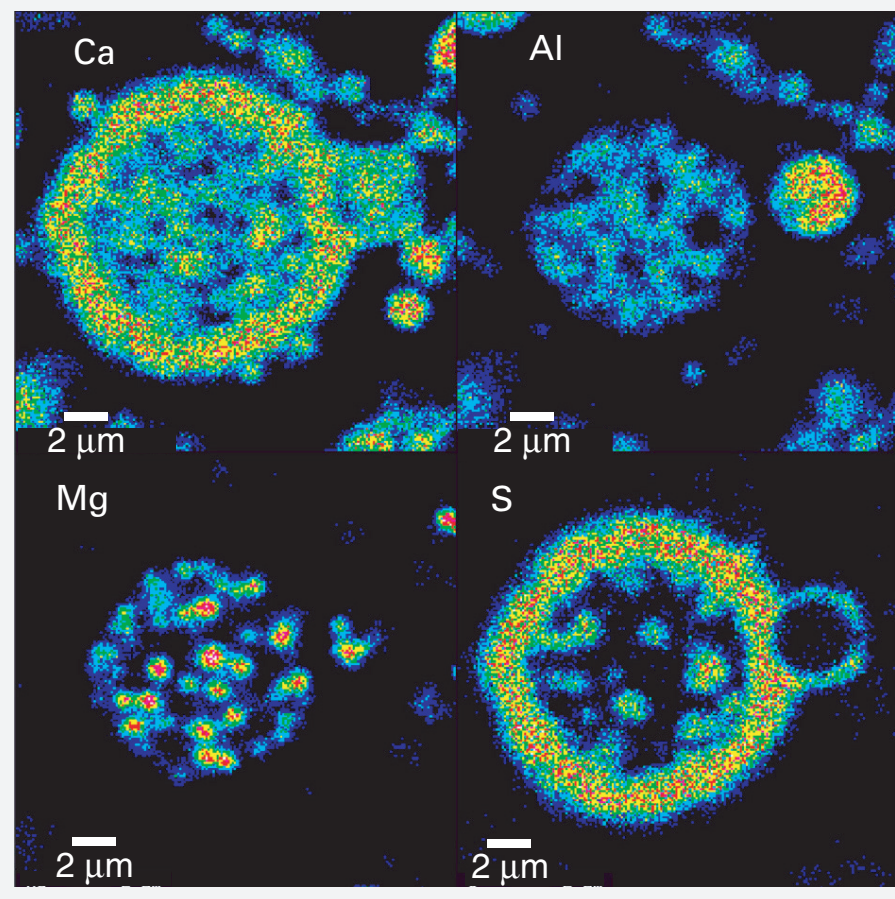

Figure 5. Element intensity maps showing relative abundances and distribution of calcium (Ca), aluminum (Al), magnesium ( $\mathrm{Mg})$, and sulfur $(\mathrm{S})$ in the same Indiana power-plant fly ash grain. The bright areas in the lower left image are periclase crystals (MgO).

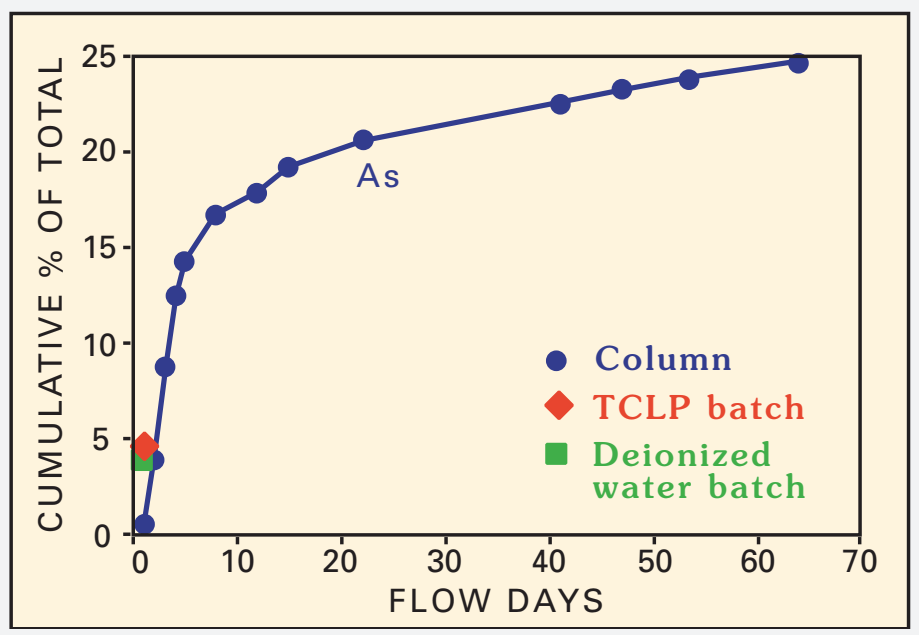

Figure 6. The percentage of arsenic (As) leached from a Kentucky power-plant fly ash (40 ppm initial As) by deionized water in a flow-through column test compared to the percentage leached by two 18-hour batch tests. TCLP=U.S Environmental Protection Agency's toxicity characteristic leaching protocol. interactions can be characterized by techniques that (1) allow mixing of solids and leaching solutions that simulate environmental conditions and (2) determine modes of occurrence of trace elements in coal and CCPs.

Leaching experiments range in duration and severity of chemical treatment. Different types of leaching tests provide different types of valuable information on the leaching behavior of coal and CCPs. As an example, figure 6 shows the percentage of arsenic (As) leached from a Kentucky power-plant fly ash (40 ppm initial As) in two 18-hour batch tests with different leaching solutions versus a flow-through column test with deionized water. The flow-through column test simulates longterm ash disposal in the natural environment. The amount of arsenic leached in the batch tests is relatively small, but the cumulative amount of arsenic leached during a column test can be a significant amount.
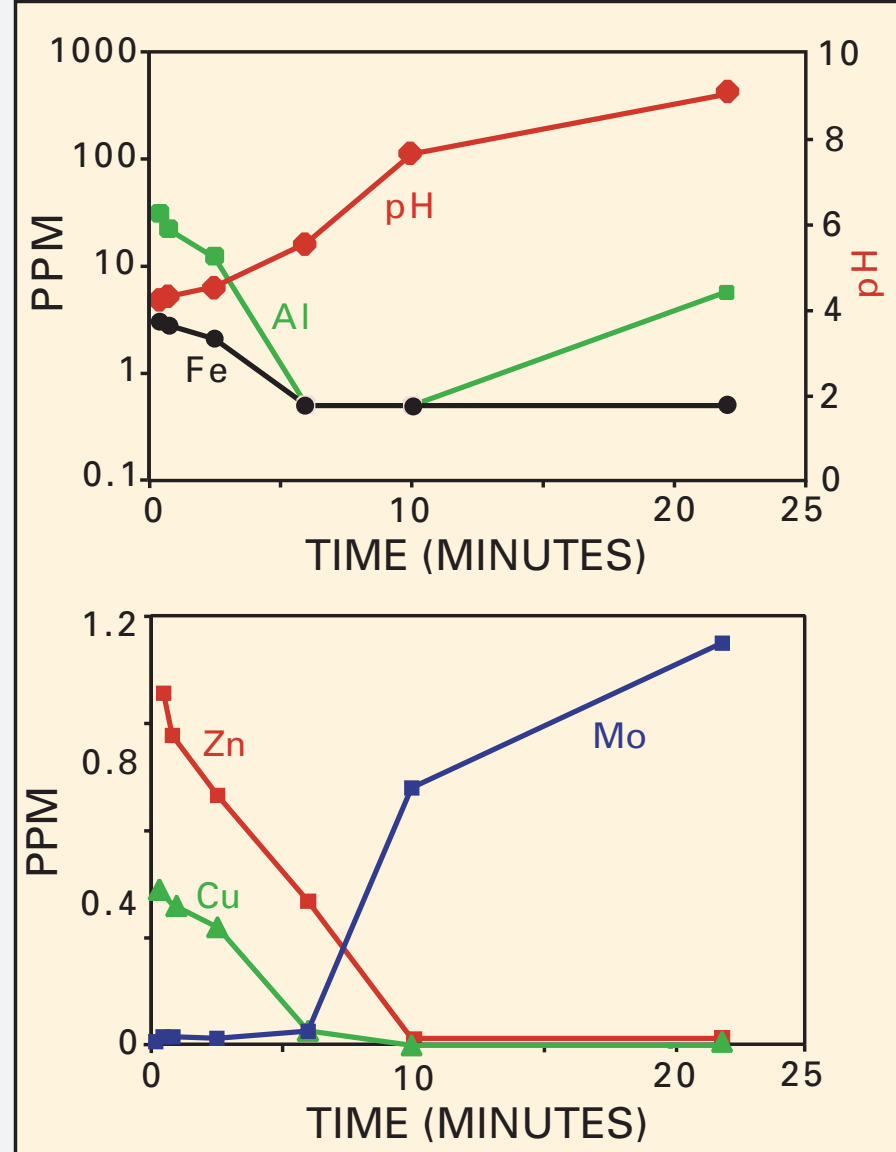

Figure 7. Leachate concentration of aluminum (Al), copper (Cu), iron (Fe), molybdenum (Mo), zinc (Zn), and pH during the leaching of a Kentucky powerplant fly ash with deionized water. 
Reactions between the solid phase, such as fly ash, and the solution change the solution composition, which affects the $\mathrm{pH}$ and the mobility of trace elements. The physical and mineralogic properties of the solid phase help identify reactants that could substantially change solution composition. As an example, figure 7 shows the $\mathrm{pH}$ and concentration of five selected elements in a solution of deionized water in contact with the Kentucky plant fly ash. The $\mathrm{pH}$ of the solution is initially acidic $(\mathrm{pH}<4)$ and most of the trace metals have high concentrations in solution because of the rapid dissolution of a sulfate (steklite, $\mathrm{KAl}\left(\mathrm{SO}_{4}\right)_{2}$ ) surface coating (fig. 8) on the fly ash grains (Rice and others, 1999). After a few minutes, however, a reaction between lime $(\mathrm{CaO})$ in the fly ash and the solution begins to raise the $\mathrm{pH}$. Secondary phases (Al and Fe oxyhdroxides) form as a result of the $\mathrm{pH}$ increase and these phases co-precipitate some of the trace metals (for example, $\mathrm{Fe}, \mathrm{Zn}, \mathrm{Cu}$; fig 7) and lower their dissolved concentration. In contrast, the dissolved concentration of molybdenum (Mo) increases as the $\mathrm{pH}$ increases (fig. 7). The $\mathrm{pH}$ dependency of trace metal mobility emphasizes the importance of solution-solid phase interaction in controlling trace element mobility.

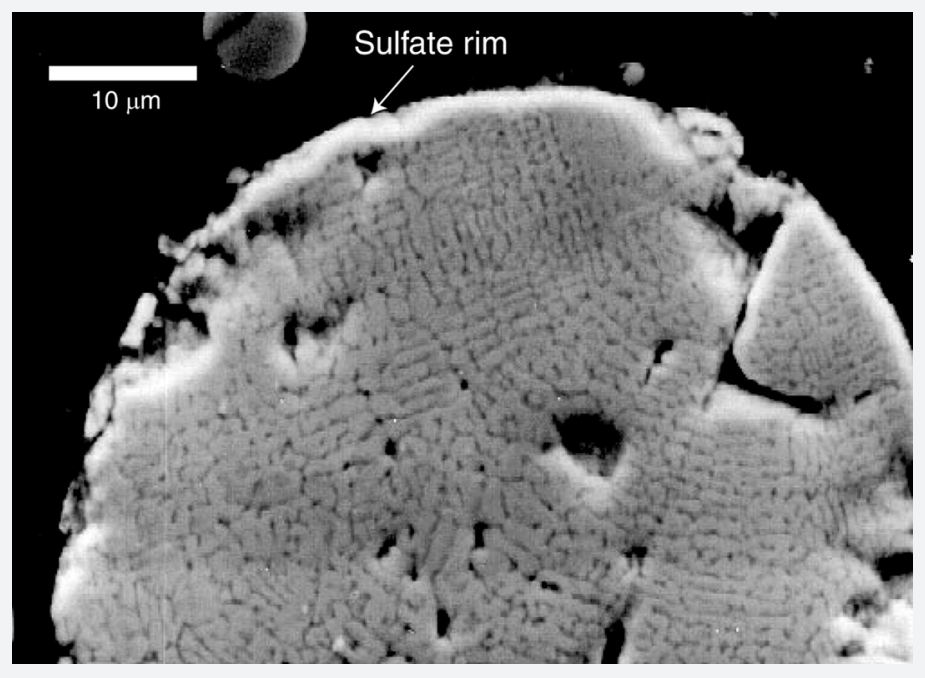

Figure 8. Scanning electrom microscope image of a spinel-rich Kentucky power-plant fly ash grain with a sulfate (steklite, $\left.\mathrm{KAl}\left(\mathrm{SO}_{4}\right)_{2}\right)$ enriched coating, which has been shown to control initial $\mathrm{pH}(<4)$ and leaching of some trace metals-see figure 7.

\section{Summary}

Many factors contribute to and control how coal and fly ash will affect the environment and the solutions that they contact. Particle size, coal rank, amount of ash, coal mineralogy, and the trace element content are important variables controlling the combustion and leaching of coal. For fly ash, the original composition of the feed coal, the combustion conditions, the size of the fly ash particles, and the fly ash mineralogy all influence the distribution and mobility of trace metals.

The USGS Energy Resources Program, in response to the need for scientific support for national policy decisions, continues to study the environmental effects of coal utilization. Coal environmental studies focus on the variability of coal quality and on the environmental and human-health impacts of using coal as one of the Nation's primary energy sources. The USGS continues to provide objective and reliable data on the amount and behavior of trace elements in coal and coal combustion products to better understand their effects on our environment.

\section{Suggested Reading}

Affolter, R.H., Brownfield, M.E., and Breit, G.N., 1997, Temporal variations in the chemistry of feed coal, fly ash, and bottom ash from a coal-fired power plant: Proceedings of the 1997 International Ash Utilization Symposium, Lexington, Kentucky, October 20-22, 1997, p. 757-764.
Affolter, R.H., Brownfield, M.E., and Cathcart, J.D., 1999, Chemical variation of feed coal and coal combustion products from an Indiana power plant utilizing low sulfur Powder River Basin coal: Proceedings of the 1999 International Ash Utilization Symposium, Lexington, Kentucky, October 18-20, 1999, CD-ROM, 7 p.

Brownfield, M.E., Affolter, R.H., Cathcart, J.D., O'Connor, J.T., and Brownfield, I.K., 1999, Characterization of feed coal and coal combustion products from power plants in Indiana and Kentucky: The Proceedings of the 24th International Technical Conference on Coal Utilization and Fuel Systems, March 8-11, 1999, p. 989-1000.

Brownfield, M.E., Cathcart, J.D., and Affolter, R.H., 1997, Characterization of feed coals and waste products from a coal-burning power plant in Kentucky: Proceedings of the 1997 International Ash Utilization Symposium, Lexington, Kentucky, October 20-22, 1997, p. 780-784.

Cathcart, J.D., Reynolds, R.L., Brownfield, M.E., and Hower, J.C., 1997, Chemical, mineralogical, and magnetic characterization of sized fly ash from a coal-fired power plant in Kentucky: Proceedings of the 1997 International Ash Utilization Symposium, Lexington, Kentucky, 1997, October 20-22, 1997, p. 785-792.

O'Connor, J.T., 1997, Silicate fly ash classification based on exsolution mineralogy: Proceedings of the 1997 International Ash Utilization Symposium, Lexington, Kentucky, October 20-22, 1997, p. 692-699.

O’Connor, J.T., and Meeker, G.M., 1999, Liquidus (Ca+Mg)-rich exsolution phases in low-sulfur fly ash: The Proceedings of the 24th International Technical Conference on Coal Utilization and Fuel Systems, March 8-11, 1999, p. 333-342.

Rice, C.A., Breit, G.N., Fishman, N.S., and Bullock, J.H., Jr., 1999, Leachability of trace elements in coal and coal combustion products: The Proceedings of the 24th International Technical Conference on Coal Utilization and Fuel Systems, March 8-11, 1999, p. 355-366.

U.S. Statutes at Large, 1990, Provisions for attainment and maintenance of National ambient air quality standards: Public Law 101-549, 101st Congress, 2nd Session, v. 104, pt. 4, p. 2353-3358.

Zielinski, R.A., and Finkelman, R.B., 1997, Radioactive elements in coal and fly ash: Abundance, forms, and environmental significance: U.S. Geological Survey Fact Sheet FS-163-97, 4 p.

\section{For more information please contact:}

Michael E. Brownfield, U.S. Geological Survey (303) 236-7767; e-mail: mbrownfield@usgs.gov

\section{For information on topical studies, contact:}

Element variation: Ronald H. Affolter, U.S. Geological Survey (303) 236-7752; e-mail: affolter@usgs.gov

X-ray diffraction: James D. Cathcart, U.S. Geological Survey (303) 236-7780; e-mail: cathcart@usgs.gov

Microbeam techniques: Gregory P. Meeker, U.S. Geological Survey (303) 236-3188; e-mail: gmeeker@usgs.gov

Leaching: Cynthia A. Rice, U.S. Geological Survey (303) 236-1989; e-mail: crice@usgs.gov

Radionuclides: Robert A. Zielinski, U.S. Geological Survey (303) 236-4719; e-mail: rzielinski@usgs.gov

Coal petrography: James C. Hower, University of Kentucky, Center for Applied Energy Research

(606) 257-0261; e-mail: hower@caer.uky.edu 